\title{
Perilaku Masyarakat Desa terhadap Penyakit Malaria di Masa Pandemi Covid-19
}

\author{
Fabio B. Rading, ${ }^{1}$ Victor D. Pijoh, ${ }^{2}$ Josef S. B. Tuda ${ }^{2}$
}

\author{
${ }^{1}$ Program Studi Pendidikan Dokter Fakultas Kedokteran Universitas Sam Ratulangi, Manado, \\ Indonesia \\ ${ }^{2}$ Bagian Parasitologi Fakultas Kedokteran Universitas Sam Ratulangi, Manado, Indonesia \\ Email: bryanrading@gmail.com, joseft@unsrat.ac.id
}

\begin{abstract}
To date, the number of malaria cases in North Sulawesi is still quite high which may be influenced by community behavior. Kauditan District, especially in Kaima village, is one of the areas in North Minahasa Regency that has the highest incidence of malaria. Moreover, community's behavior has changed greatly during the current Covid-19 pandemic. This study was aimed to determine the behavior of the Kaima village community, Kauditan District, North Minahasa Regency towards malaria during the Covid-19 pandemic. This was a descriptive study. There were 100 people of Kaima village as respondents in this study. The results showed that based on the level of knowledge about malaria, 66 respondents $(66 \%)$ had good knowledge. Based on the attitudes towards malaria, 95 respondents $(95 \%)$ had good attitudes. Based on the action against malaria, 61 respondents (61\%) had good action. In conclusion, during Covid-19 pandemic, people of Kaima village had good knowledge about the malaria incidence, however, there was lack of knowledge about the types and activities of biting of the mosquitoes. Moreover, people of Kaima village had good attitude and good actions towards malaria incidence, albeit, there are still obstacles in implementing these actions.
\end{abstract}

Keywords: behavior; malaria; Covid-19

\begin{abstract}
Abstrak: Angka kasus malaria di Sulawesi Utara yang masih cukup tinggi mungkin dipengaruhi oleh perilaku masyarakat. Kecamatan Kauditan terlebih khusus di desa Kaima merupakan salah satu daerah di Kabupaten Minahasa Utara yang memiliki angka kejadia malaria tertinggi. Di masa pandemi Covid-19, perilaku masyarakat sudah sangat berubah. Penelitian ini bertujuan untuk mengetahui perilaku masyarakat Desa Kaima Kecamatan Kauditan Kabupaten Minahasa Utara terhadap penyakit malaria di masa pandemi Covid-19. Jenis penelitian ialah deskriptif. Terdapat 100 responden dalam penelitian ini yang merupakan masyarakat Desa Kaima. Hasil penelitian mendapatkan bahwa berdasarkan tingkat pengetahuan terhadap penyakit malaria didapatkan subjek yang berpengetahuan baik sebanyak 66 orang (66\%). Berdasarkan sikap terhadap penyakit malaria didapatkan subjek yang mempunyai sikap baik sebanyak 95 orang (95\%). Berdasarkan tindakan terhadap penyakit malaria didapatkan subjek yang mempunyai tindakan baik sebanyak 61 orang $(61 \%)$. Simpulan penelitian ini ialah pada masyarakat Desa Kaima di masa pandemi Covid-19, pengetahuan terhadap kejadian malaria secara keseluruhan sudah baik namun masyarakat masih kurang pengetahuan mengenai jenis dan aktivitas mengigit nyamuk, Sikap masyarakat dan tindakan masyarakat terhadap kejadian malaria sudah baik, namun terdapat kendala dalam pelaksanaan tindakan tersebut.
\end{abstract}

Kata kunci: perilaku masyarakat; malaria; pandemi Covid-19

\section{PENDAHULUAN}

Malaria adalah penyakit yang disebabkan oleh parasit tergolong Plasmodium yang

ditularkan melalui nyamuk Anopheles betina. Terdapat empat jenis Plasmodium 
yang mengingfeksi manusia, yaitu Plasmodium falciparum, Plasmodium vivax, Plasmodium ovale dan Plasmodium malariae. Penyakit malaria dapat terjadi pada semua kelompok usia, namun tersering berisiko tinggi yaitu bayi, anak balita, dan ibu hamil. Malaria memiliki gejala klinis yang dapat bermanifestasi ringan hingga berat dan tergantung sistem kekebalan dari penderita. Menurut World Health Organization (WHO) pada tahun 2015 prevalensi kasus malaria di dunia mencapai 214 juta kasus. Terdapat 3,2 miliar populasi di dunia berisiko terkena malaria, dan tercatat sudah 438.000 juta orang yang meninggal akibat malaria dan $65 \%$ kematian yang terjadi pada anak di bawah usia lima tahun. ${ }^{1}$ Prevalensi malaria di Indonesia pada tahun 2013 mencapai dua kali lipat dibanding dengan tahun 2010 seperti pada kelompok yang memiliki resiko tinggi yaitu anak yang berusia 1-9 tahun dan ibu hamil yang memiliki kasus positif malaria yang cukup tinggi yaitu 1,9\% dibanding kelompok lain. Penduduk perkotaan hanya memiliki kasus positif malaria sebesar $0,8 \%$ dan penduduk pedesaan $1,7 \% .^{2}$ Minahasa Utara termasuk Kabupaten dengan angka kejadian malaria yang cukup tinggi. Berdasarkan data dari Dinas Kesehatan Kabupaten Minahasa Utara, kasus positif malaria berjumlah $3.477 .^{3}$

Kecamatan Kauditan merupakan salah satu daerah di Kabupaten Minahasa Utara yang memiliki angka kejadian malaria tertinggi, terlebih khusus di Desa Kaima yang memiliki kasus penyakit malaria terkonfirmasi pemeriksaan laboraturium. Kejadian malaria dipengaruhi oleh banyak factor, salah satunya ialah perilaku. Faktor perilaku terutama berperilaku hidup sehat merupakan hal penting dalam tindakan pencegahan terhadap penyakit malaria, namun hal tersebut belum disadari dan dilakukan oleh masyarakat. ${ }^{4}$

Perilaku adalah totalitas seseorang terhadap pemahaman dan aktivitas yang dihasilkan melalui interaksi faktor internal dan eksternal. Perilaku mempunyai bentangan yang sangat luas serta kompleks. Hal tersebut dapat berubah terlebih lagi pada masa pandemi Severe Acute Respiratory Syndrome Coronavirus (SARS-CoV2), atau yang umum dikenal sebagai corona virus disease (Covid-19). Penyakit Covid-19 merupakan infeksi coronavirus jenis baru yang belum pernah diidentifikasi sebelumnya pada manusia. Penyakit ini ter-tular dengan cara droplet melalui mata, hidung, dan mulut. Untuk melakukan upaya agar tidak tertular Covid-19, masyarakat diminta untuk melakukan protokol kese-hatan. Penyakit coronavirus mulanya terjadi di Negara Cina, namun akhirnya meluas hingga ke semua negara, dan salah satunya ialah Indonesia. $^{5}$

\section{METODE PENELITIAN}

Penelitian ini dilakukan pada bulan September-November 2020 di Desa Kaima. Jenis penelitian ialah survei deskriptif. Populasi pada penelitian ini ialah semua penduduk yang berada di Desa Kaima Kecamatan Kauditan Kabupaten Minahasa Utara. Sampel penelitian diperoleh dengan menggunakan metode purposive sampling yang berjumlah 100 penduduk Desa Kaima. Kriteria inklusi penelitian ialah masyarakat yang pernah dan belum pernah terinfeksi penyakit malaria sedangkan kriteria eksklusi ialah pada saat diberikan kuisioner tidak dapat dihubungi. Penelitian ini hanya menggunakan variabel tunggal yaitu perilaku masyarakat Desa Kaima terhadap penyakit malaria.

Penyebaran kuesioner untuk memperoleh data atau informasi yang berkaitan dengan wawancara terhadap responden penelitian menggunakan instrumen penelitian dalam bentuk kuesioner. Untuk skor penilaian kuisioner terhadap pengetahuan, sikap, dan tindakan ialah: Baik bila $>75 \%$ dan kurang baik bila $\leq 75 \%$. Pengumpulan data dilakukan oleh penulis dibantu oleh petugas Puskesmas yang telah dilatih dan berlatar belakang pendidikan kesehatan.

\section{HASIL PENELITIAN}

Tabel 1 memperlihatkan hasil skor penilaian kuisioner terhadap pengetahuan, sikap, dan tindakan responden. Sebagian besar responden memiliki pengetahuan, 
sikap, dan tindakan yang baik terhadap kejadian malaria di masa pandemi Covid-19.

Tabel 1. Hasil skor penilaian kuisioner terhadap pengetahuan, sikap, dan tindakan responden terhadap kejadian malaria di masa pandemi Covid-19

\begin{tabular}{ccc}
\hline Perilaku & Baik & $\begin{array}{c}\text { Tidak } \\
\text { baik }\end{array}$ \\
\hline Pengetahuan & $66 \%$ & $34 \%$ \\
Sikap & $95 \%$ & $5 \%$ \\
Tindakan & $61 \%$ & $39 \%$ \\
\hline
\end{tabular}

\section{BAHASAN}

Penelitian ini menilai perilaku masyarakat yang berhubungan dengan kejadian malaria. Pengetahuan yang kurang baik pada responden penelitian ini sebagian besar ialah pada pengetahuan mengenai jenis nyamuk, waktu aktivitas nyamuk Anopheles aktif menggigit, apakah penyakit malaria menular atau tidak, dan bagaimana cara penularannya. Hasil penelitian ini sejalan dengan penelitian yang dilakukan oleh Akay et $\mathrm{al}^{6} \mathrm{di}$ Kecamatan Silia Raya Kabupaten Minahasa Tenggara yang mendapatkan pengetahuan masyarakat mengenai cara penularan penyakit malaria hanya sebesar $32 \%$.

Kurang baiknya pengetahuan masyarakat terhadap penyakit malaria di masa pandemi sekarang ini dapat disebabkan oleh beberapa faktor, antara lain edukasi dan promosi yang kurang terkait penyakit malaria baik melalui media massa maupun media sosial dibandingkan dengan sosialisasi Covid-19. ${ }^{6}$ Menurut Notoatmodjo, pengetahuan merupakan informasi yang ditemukan dan diperoleh manusia melalui pengamatan akal untuk mengenali suatu benda atau kejadian yang belum pernah dilihat atau dirasakan sebelumnya. Berdasarkan definisi tersebut maka tingkat pengetahuan seseorang dipengaruhi oleh beberapa faktor yaitu pemberi informasi, penerima informasi, serta media dan isi informasi itu sendiri. Di era pandemi Covid19 saat ini informasi dan promosi kesehatan yang didapatkan oleh masyarakat lebih banyak membahas mengenai Covid-19 dibandingkan malaria, mulai dari siaran TV, radio, sosialisasi pemerintah, dan internet. Dengan demikian umumnya masyarakat lebih tertarik dengan informasi tentang Covid-19 dibanding dengan penyakit yang lain termasuk malaria.?

Sikap masyarakat Desa Kaima tentang kejadian malaria di masa pandemi sudah baik. Hal ini selaras dengan penelitian oleh Waris et $\mathrm{al}^{8}$ di desa Kekayap Kabupaten Nunukan Provinsi Kalimantan Timur yang mendapatkan sikap yang baik dari masyarakat terhadap malaria sebanyak $90 \%$. Menurut Trow, ${ }^{9}$ sikap didefinisikan sebagai suatu kesiapan mental atau emosional dalam beberapa jenis tindakan pada situasi yang tepat. Berdasarkan definisi ini, Trow lebih menekankan kesiapan mental atau emosional sebagai suatu objek, dimana terdapat dua faktor yang memengaruhi sikap masyarakat yaitu faktor emosional dan faktor mental. Sebagian besar masyarakat Desa Kaima memiliki sikap yang baik terhadap kejadian malaria di masa pandemi sekarang ini disebabkan masyarakat memiliki motivasi yang didasarkan pada kesiapan emosional dan mental dalam menyikapi berbagai aspek pencegahan dan penanggulangan penyakit malaria.

Berdasarkan hasil penelitian ini didapatkan bahwa tren rendahnya persentase baik dari aspek tindakan dibanding aspek sikap masyarakat disebabkan oleh adanya pandemi yang sementara terjadi. Diduga krisis ekonomi menyebabkan turunnya pendapatan masyarakat saat pandemi sehingga masyarakat kurang memanfaatkan penggunaan obat anti nyamuk oles (repellent). Selain itu masyarakat lebih memilih untuk membeli hand sanitizer dan sabun cuci tangan dibanding membeli obat anti nyamuk oles. Masyarakat juga lebih memilih untuk mengonsumsi obat secara mandiri dibanding untuk mencari fasilitas pelayanan kesehatan, karena masyarakat takut dan cemas untuk terinfeksi penyakit Covid-19. Di masa pandemi ini seluruh lapisan masyarakat lebih berfokus pada sosialisasi tentang penyakit Covid-19 dibandingkan malaria. Dampak penerapan Pembatasan Sosial Berskala Besar (PSBB) juga mengharuskan masyarakat lebih memilih untuk beraktivitas di dalam 
rumah atau di halaman, yang mungkin menyebabkan mudahnya orang digigit nyamuk terutama ketika beraktivitas di halaman. Selain itu, di era modern ini, masyarakat jarang menggunakan kelambu saat tidur.

Menurut Notoatmodjo, ${ }^{10}$ tindakan yang tercakup dalam domain psikomotorik mempunyai empat tingkatan yaitu persepsi, respon imun, mekanisme, dan adaptasi. Persepsi (perception) yaitu mengenal dan memilih berbagai objek sehubungan dengan tindakan yang akan diambil merupakan praktek tingkat pertama. Respon terpimpin (guided response) yaitu dapat melakukan sesuatu sesuai dengan urutan yang benar dan sesuai dengan contoh merupakan indikator praktek tingkat kedua. Mekanisme (mechanism) yaitu bila seseorang telah dapat melakukan sesuatu dengan benar secara otomatis atau sesuatu itu sudah merupakan kebiasaan maka ia sudah mencapai praktek tingkat tiga. Adaptasi (adaptation) yaitu suatu praktek atau tindakan yang sudah berkembang dengan baik. ${ }^{10}$ Masa pandemi Covid-19 sekarang ini juga mendorong masyarakat untuk beradaptasi dengan penerapan kebiasaan baru yang dicanangkan oleh pemerintah sehingga mengubah persepsi, respon, prioritas, serta fokus masyarakat dari pencegahan penyakit malaria ke Covid-19.

Keterbatasan penelitian ini ialah responden sulit dihubungi pada saat penelitian.

\section{SIMPULAN}

Di masa pandemi Covid-19 pengetahuan masyarakat Desa Kaima terhadap kejadian malaria secara keseluruhan sudah baik namun pengetahuan mengenai jenis dan aktivitas mengigit nyamuk masih kurang. Sikap dan tindakan masyarakat terhadap kejadian penyakit malaria secara keseluruhan sudah baik namun terdapat kendala dalam pelaksanaan tindakan tersebut.

\section{Konflik Kepentingan}

Penulis menyatakan tidak terdapat konflik kepentingan dalam studi ini.

\section{DAFTAR PUSTAKA}

1. WHO Global Malaria Programme. World Malaria Report 2015. WHO Library Cataloguing-in-Publication Data: WHO, 2015. Available from: https:// www. mmv.org/sites/default/files/uploads/docs /publications/World\%20Malaria\%20Re port.pdf

2. Badan Penelitian dan Pengembangan Kesehatan Kementerian Kesehatan RI. Riset Kesehatan Dasar - RISKESDAS 2013. Jakarta: Kementerian Kesehatan RI, 2013. Available: http://labdata.litbang. kemkes.go.id/images/download/laporan /RKD/2013/Laporan_riskesdas_2013_f inal.pdf

3. RPIJM 2015-2019 Kabupaten Minahasa Utara. Available from: https://sippa. ciptakarya. pu.go.id/sippa_online/ws_ file/dokumen/rpi2jm/DOCRPIJM_de4a bad86b_BAB\%20IIIBAB\%20III\%20O K\%20FINAL.pdf

4. Data puskesmas Kauditan tahun 2017-2020.

5. Aziza L, Aqmarina A, Ihsan M (editors). Pedoman Pencegahan dan Pengendalian Coronavirus Disease (COVID19). Jakarta: Kementerian Kesehatan RI, 2020.

6. Akay CS, Tuda JSB, Pijoh VD. Gambaran pengetahuan masyarakat tentang penyakit malaria di Kecamatan Silian Raya Kabupaten Minahasa Tenggara. eBiomedik. 2015:3(1):435-41.

7. Notoatmojo S. Ilmu Perilaku Kesehatan. Jakarta: Rineka Cipta, 2010.

8. Waris L, Suryatinah Y, Sulasmi S. Pengetahuan, sikap dan perilaku masyarakat terhadap malaria di Desa Kekayap Kabupaten Nunukan Provinsi Kalimantan Timur. Jurnal Buski: Epidemiology and Zoonosis Journal. 2012;4(1):36-40.

9. Trow MA. University and Society: Essay of the Social Role of Research and Higher Education. London: Jessica Kingsley Publishers, 1991.

10. Notoatmojo S. Promosi Kesehatan. Teori dan Aplikasi. Jakarta: Rineka Cipta, 2003. 